\title{
Homo Faber and the Technological Progress Consequences
}

\author{
Galina Chernogortseva \\ Bauman Moscow State Technical University \\ 5/1, 2nd Baumanskaya St. \\ Moscow, 105005 Russia \\ E-mail: irbiscotta@mail.ru
}

\author{
Valeriy Nekhamkin \\ Bauman Moscow State Technical University \\ 5/1, 2nd Baumanskaya St. \\ Moscow, 105005 Russia \\ E-mail: nechamkin@rambler.ru
}

\begin{abstract}
The work analyzes the present-day global problems, which result from the rapid development of science and technology. We consider the liaising between the technological progress and human society at different stages of its development. The author analyzes such problems as the influence of mass communication on people, the unification of views, thoughtlessness, escape from thinking and others, caused by the scientific and technological progress, the implementation of technological ideas, the intensification of human manufacturing activity. We have found out the changes that a human being deals with due to the technology influence. The article shows the significance of philosophy for solving the existing problems and possible ways to resolve them.
\end{abstract}

Keywords-nature; society; human being; technology; science; ecology; philosophy

\section{INTRODUCTION}

Industrial civilization has actualized the idea of Heraclitus according to which the human being must live, listening attentively to the power of things, in order to act in consonance with them. The creative nature of the human being at all times encouraged him to change the world, in which there was always something that did not satisfy him completely or was absolutely unacceptable. Creating the instruments of labor for procuring daily bread, the human being changed the natural world by means of his thought and labour in accordance with his needs, interests and goals.

The human being has never been satisfied by the world. And since people can live only doing something, any labor activity always helped to take in the materials of nature and make desirable changes.

In the course of time both the needs and human capabilities have continually been increasing. Besides, the philosophical perceptions of the human being "fundamentally change from epoch to epoch and are full of special features and nuances depending on the geographical, economical, ethnical life conditions, formed within the boundaries of a particular mindset" [1].

\section{TRADITIONAL SOCIETY}

So, in the primitive society, often named traditional, the human being was first of all focused on satisfying the vital needs. Adaptive type of management was dominating. There were few opportunities to change nature. Changes were mostly naturally-occurring or caused by reasons beyond human control. So, for example, livestock could trample the pasture-land, and as a result people had to find other places for cattle grazing. Lightning or careless handling of fire could burn the forest or habitation.

Increasing demand makes the human being to use more intensively the materials and forces of nature. With ever increasing frequency "people have to meet the challenge of the environment, trying to overcome the dependence on wildlife", which brings the human being to improving the existing instruments of labor and continuously creating the new ones [2].

Separation of mental labour from manual labour considerably stimulated the process of technical creativity. The human being increasingly invaded nature, building houses, ships and buildings intended for public use, mastering crafts. At this stage natural resources seem to be unlimited. People are so much concerned with their own survival and self-preservation that they do not think about the consequences of their intervention in nature. They do not care about the consequences of their activity, despite the fact that there appears a belief in the ancient Greek thought that the best life for a human being is life in harmony with the cosmos, which acts as an example of orderliness and beauty for all things.

Over the centuries the predominance of manual equipment and manual labour made the problem of the relationship between man and nature needless. Of course, the extent of natural resources acquisition gradually increased, but nothing portended of the coming problems.

\section{COHESION OF SCIENCE AND TECHNOLOGY}

The appearance of mechanical equipment and machine labour coming from the development of market economy significantly intensified the use of the materials and forces of nature. The reclamation of territories began by means of "mining, agriculture, civil engineering" [3]. The essential factor was the formalization of science as the formation of social institutions, which provided the appearance of progressively advanced and efficient technologies. 
Fundamental scientific ideas had a significant impact on the evolution of technical thought, inducing the human being to create more and more improved technical equipment. According to M. Heidegger the reality itself encourages the man to manipulate nature using technical equipment, and in the same manner that the host leaving the door unlocked provokes robbery, the reality must be in some way responsible for being exploited by the man.

These circumstances resulted in a situation where the human being has begun to see the world as an open infinite space for the implementation of technical ideas in order to get more and more usefulness and benefits. The amalgamation of the science with technological advances has a serious impact on all spheres of development in social life. Since the first precondition for the existence of any society is living human individuals, human life has also undergone certain changes. Smoked by the chimney-stalks sky, as well as the quality of water and food make people think about the limits of their intervention on the state of nature. It is becoming of vital importance for both the individual and the humanity on the whole how much the transformation of nature by means of the ever more powerful technical means is useful and advantageous for the human being.

Scientific and technological progress is quite able to influence the destiny of the mankind and the whole world. As in the process of technical creativity the destructive means are created faster than the curative ones, the matter of possibilities and limits of controlling the use of scientific and technical achievements is becoming urgent.

\section{PeOPle AND TeChNOlogy}

It is obvious that the fundamental principle of human life consists in recognizing the primacy of humanitarian principles over technical ones. In his work "Being and Time" M. Heidegger claimed that science and equally valuable technology refer to the essential phenomena of life. Their joint development creates a situation when "any human doing is now comprehended and realized as the culture" [4].

Ancient Greek philosophy defended the idea of submitting different kinds of technical activity to the interpretations of good accepted in society as well as to the political structures, within and under the aegis of which the technical activity is carried out. It is becoming apparent that the current development level of technology raises the question of the survival and self-preservation of the man and humankind in their uniqueness and identity. This is precisely why, according to N.A. Berdyaev, "the question about technology has become the question about the destiny of man and the destiny of culture" [5]. The man endlessly believes in technology, in its force, power, capabilities and unlimited development and due to this is ready to change his image under the influence of the object of his love [6]. Today, more than ever "the machine dictates its laws, the machine wants the man to accept its image and likeness" [7]. The technology, having become the last love of man, objectifies the creative ideas of man. The limit of objectification is the technology power over the man. In the contemporary world the technology not only serves the man, but also conquers him [8].

Various intelligent devices such as computers, smartphones, electronic networks and technologies, numerous virtual worlds, powerful servers, allowing us to store durably information about anything and everything, need and tame the human being. They give him an opportunity to feel if not a creator, then exactly the cocreator of the world, life and mind [9].

The technology in its pervasive development turns the man away from the nature, requires the formation of the new type of adaptation to the world, notably to the new, significantly changed world - the world of technical reality. It is not surprising that as far back as in the last century N.A. Berdyaev expressed fears regarding whether the man would be able "to breathe in the new, electrical and radioactive atmosphere, in the new cold, metallic reality deprived of the vital warmth" [10]. We still do not know at all, he wrote in the years preceding World War II, how destructive for the man is that atmosphere, which is created by his own technical inventions and discoveries, especially with consideration for the important circumstance that man's ingenuity in creating the tools of destruction has a consistent trend to exceed the ingenuity in the curative technology. Today it has resulted in a situation where the technology itself at the stage of the most impressive development has become a sort of the test on the survival of the man and humankind, test on persisting by the human being his fundamental nature and culture.

Industrial civilization encompasses the man with more and more devices and appurtenances greatly facilitating the man's labor efforts and his everyday life, generates global problems important for all people in the world [11]. The volume of these problems is increasing. The man is not always able to control them, taking appropriate measures. It can often be difficult and sometimes impossible. For instance, the complication of modern life, directly related to the scientific and technological progress, makes the man to protect himself from excessive social contacts, and the communication becomes practically convenient and beneficial interaction of people aimed at achieving only pragmatic benefits. The interaction with the computer becomes preferable to communicating with colleagues, neighbors or family members [12].

\section{INDOCTRINATION}

The problem of the optimal ratio between the population and the volume of those resources that exist in nature has become very serious. Ecology when translated literally means the science of home, and the home is characterized by the interaction, relationship, understanding, the style of communication between different generations of people. Some researchers note the increasing difficulties occurring when the older and the younger generations try to understand each other. Sometimes this is so much the case that the representatives of one generation perceive the representatives of another generation as people from the foreign ethnos, 
which makes it difficult to solve the problems of the consolidation of society [13].

Many researchers pay attention to the fact that strengthening the influence of mass media and fixed behaviour are related to the increasing unification of people's views and perceptions and consequently their mental characteristics [14] [15]. It happens that a person, who deliberately evades the impact of mass media, is perceived by others as a pathological subject. The increasing unification of views, which is often called indoctrination, leads to the fact that an increasing number of people prefer to be a man of the mass, rather than individuals. At the same time, "a person of the mass can be a representative of any social group or society" [16]. According to the definition of S. Kierkegaard, "the only" man can be found more rarely. It is safe, convenient, profitable and useful to be a person of the mass. Deprived of any notions of responsibility, the man of the mass is always "pleased that he is similar to other people", satisfied with his existence, seeks to avoid situations that require a decision [17]. The main aspiration of the man of the mass is to be like everyone else, to think like everyone else, to act like everyone else.

"Since the reality consists in the uniformity of a systematic calculation, - says M. Heidegger in his work "Being and time", - then the man must also be unified in order to stay at the height of the real" [18]. Increased indoctrination of society mitigates individual tastes and beliefs. People's preoccupation by the immediate questions, the current day practical issues brings into a question the connection with cultural tradition, amplifies the penchant for mass culture. Mass-produced technical devices combined with mass culture lead to weakening the social ties, create the desire to evade responsibility alleging the authority of computer printouts no less than other authorities. In this connection there are concerns that our society will increasingly be filled with machine-like people, satisfied with automatic machines, preoccupied with work, satisfied with the safe existence in the status of an average person, "a man of the mass", longing for impersonal existence (José Ortega y Gasset).

The modern unnatural world of technical reality makes significant changes in the human habitat. Information has become an independent entity, along with the matter and energy. Today's reality implies being a society of the industry of records, self-reproducing itself. The power of the information and computer world is compared with the power of mountain ranges, tectonic shifts, but this power, solving some problems, creates the others.

\section{THOUGHTLESSNESS}

According to M. Heidegger the most ominous guest of the modern world is thoughtlessness. Thoughtlessness creates a situation of complete identification of nature and spirit with the essence of technology. Thanks to technical achievements, learning absolutely everything is available so quickly and so easily that it is quickly forgotten. The man escapes from thinking, creating a basis for thoughtlessness. Indeed, if it is possible to become deaf because of having a sense of hearing, and only the one who can see may become blind, then the man can become thoughtless only because by virtue of his nature the man is able to think - and that is his destiny.

Modern man denies his shift away from thinking, referring to the increasing volume of scientific research and technical developments. Scientific work and engineering activity always considers these conditions and reckons upon certain results, plans more and more promising good opportunities. The trouble of this activity is that it comes over the man so much that he cannot come down and think about the sense prevailing everywhere. Delighted by the results of technological activities, the human being avoids sensible reflection, supposedly useless for solving practical questions, incapable of coping with daily routine, losing the ground and floating above the reality. Furthermore, the sensible reflection requires ultimate efforts, more sensitive care than any other occupation. It must be able to wait, says M. Heidegger, like the peasant waits for the harvest. And yet everyone can go out on the path of sensible reflection. To achieve this, it is necessary to stop at the nearest and think about something most special that affects everyone here and now.

The sensible reflection can save the human being from losing the rootedness needed for the prosperity of the essence of man, thoroughly prepare for the increasing attack of technical means on the life and essence of man. M. Heidegger discovers the background of the current situation in the radical change of the ideological paradigm, when the world started to be deemed the object open for the attacks of the evaluating thought, in front of which nothing can hold the ground. The technology in its current development requires "the highest and unconditional self-development of all human abilities in order to absolutely dominate the Earth" [19].

\section{CONCLUSION}

It is impossible to stop the technological progress. This is precisely why in all areas of his life the man will be more and more involved into the system of technical devices, which require the man everywhere and all the time, entail, importune and obtrude upon him. The technological tools, whose essence, according to M. Heidegger, is the being itself comprise the value that possesses the human actions and behaviour. In order to reveal the essence of technology, there should be a man in his corresponding essence. The meaning of the world of technology is hidden from us today. In order to comprehend it and withstand the world of technology, it is needed to acquire aloofness from things and openness for secrecy. Philosophy as the sensible reflection conduces to it, since the current level of engineering achievements causes the problems beyond the competences of natural and technical sciences [20]. It is important to understand that the technology, which teaches us to achieve greatest results with the least expenditure of energy, is always a means and a tool for the purposeful activity of a man as the subject of the creative as well as engineering activity. 
In the modern world technology increasingly claims to a pivotal role in human life, forming the state of rapid dynamism, imposing the need for constant technical renewal, increasing the dependence of the man to such an extent that he loses power over his own life, balances on the verge of turning into the thing (L. Mumford). And since the forms of human communication at the personal level are either destroyed or paralyzed, and the real-life communication is increasingly frequently replaced by the supposedly pragmatically advantageous and safer virtual communication, the man has to seek protection in the transpersonal structures. "Escape from freedom" (E. Fromm) brings forth a new type of freedom - absolute freedom from responsibility and active choice [21].

Unwillingness to make a decision, realize free choice, bear the burden of responsibility, readiness to obey without thinking to any superior force have become the cause of many dramatic events during the last century.

Technology always tends to achieve greatest results at minimum cost. The man possessed with the commitment to technical creativity considers everything around him from the perspective of benefit. However, gaining immediate profit may afterwards cause serious problems capable of requiring greater efforts for controlling or even lead to an uncontrolled situation. In this regard, philosophy amidst the rush toward benefit suggests stopping and thinking about the meaning of everything that exists in the modern world. It is necessary particularly for the man, without whom there can be neither achievements, nor progress, nor history. Thinking humankind aspires to outline the terms, the ground where the man would be able to realize his essential energy and creative abilities in order to achieve security, wealth and life comfort.

\section{REFERENCES}

[1] G.V. Chernogortseva, On the problem of human being: Going back to the sources. Aktualnyeproblemygumanitarnykh i estestvennykhnauk (Contemporary problems of humanities and natural sciences), 2015, no. 06(1), p. 272.

[2] G.V. Chernogortseva,Scientistic and philosophical interpretations of the development of science and technology. Mezhdunarodnyyzhurnalgumanitarnykh i estestvennykhnauk (International journal of humanities and natural sciences), 2018, no. 2, p. 155.

[3] G.V. Chernogortseva,Scientistic and philosophical interpretations of the development of science and technology. Mezhdunarodnyyzhurnalgumanitarnykh i estestvennykhnauk (International journal of humanities and natural sciences), 2018, no. 2, p. 156.

[4] M. Heidegger,Works and reflections of various years. Moscow, Gnozis Publ., 1993, p. 135.

[5] N.A. Berdyaev, Man and Machine. Russian Studies in Philosophy, 1989, no. 2, p. 147.

[6] Ibid, p. 148.

[7] Ibid, p. 151 .

[8] Ibid, p. 151.

[9] M.V. Oseledchik, V. Yu. Ivlev, M.L. Ivleva, A new paradigm for analysing knowledge transfer processes // Proceedings of 4th International Conference on Education, Language, Art and
Intercultural

Communication 2017)Part of the series ASSEHR. Moscow, Russia, p. 766

[10] N.A. Berdyaev, Man and Machine. Russian Studies in Philosophy, 1989 , no. 2 , p. 152.

[11] T.R. Suzdaleva,Migratory processes in the context of geopolitics // VestnikTomskogogosudarstvennogouniversiteta-Filosofiyasotsiologiya-politologiya-Tomsk state university journal of philosophy sociology and political science. 2016. № 3 (36). P. 237 244. DOI: $10.17223 / 1998863 X / 35 / 25$

[12] M.V. Oseledchik, V. Yu. Ivlev, M.L. Ivleva,Using social networks in knowledge management system //Proceedings of the 2nd International Conference on Culture, Education and Economic Development of Modern Society (ICCESE 2018). Moscow, Russia. Pp.911-914.

[13] V.A. Nekhamkin, A counterfactual Challenge of the Past: Ways of Negotiation // Herald of the Russian Academy of Sciences. 2017. Vol 87. Issue 2. P. 191-198. DOI: 10.1134/S1019331617020046.

[14] N.I. Gubanov and N.N.Gubanov N.N., Global mentality as a precondition of civilizations' conflict prevention // Sotsiologicheskieissledovaniya. 2011. № 4. P. 51-58.

[15] N.I. Gubanov andN.N. Gubanov, The role of mentality in the development of society: sociocultural hypothesis // Vestnikslavianskikh kultur-bulletin of slavic cultures-scientific and informational journal. 2017. Vol. 43. № 1. P. 38-51.

[16] G.V. Chernogortseva,Scientistic and philosophical interpretations of the development of science and technology. Mezhdunarodnyyzhurnalgumanitarnykh i estestvennykhnauk (International journal of humanities and natural sciences), 2018, no. 2, p. 159.

[17] Ibid, p. 160.

[18] M. Heidegger,Works and reflections of various years. Moscow, Gnozis Publ., 1993, p. 191.

[19] Ibid, p. 119.

[20] F.V. Lazarev, S.A. Lebedev, The Philosophical Reflex: Essence, Form, Types // Voprosyphilosofii. 2016. № 6, p. 15.

[21] L. Mumford, The myth of the machine. Bulletin of Moscow University. Series 12. Political Science, 1992, no. 1, p. 67. 